\title{
Pengaruh biaya operasional, Dana Pihak Ketiga (DPK), dan Non Peforming Financing (NPF) terhadap margin murabahah Pada bank umum syariah di Indonesia
}

\author{
Zulpahmi*, Fitrisia, Eka Rizqiana \\ Universitas Muhammadiyah Prof. DR. HAMKA, Jakarta, Indonesia \\ *Email: zulpahmi@uhamka.ac.id; zulpahmi42@gmail.com
}

Keywords:
Operating Expense, Third
Fund Party, Non Performing
Financing, and Margin
Murabahah.

10.20885/JEKI.vol4.iss2.art4

\begin{abstract}
This study aims to analyze and determine whether there is a direct effect of operating expense, third fund party and non-peforming financing to margin murabahah in Sharia commercial bank in Indonesia. Research population is Sharia commercial banks in Indonesia, while sampling technique used is purposive sampling with selected sample of 5 Sharia commercial banks. Data collection technique in this study is a document review of company's Annual Report. However, techniques of processing and analyzing data are accounting analysis, descriptive statistical analysis, multiple linear regression analysis, classical assumption test, coefficient determinant coefficient analysis and hypothesis test using SPSS version 20. Based on the partial test, operating expense and third party fund have a positive and significant effect on margin murabahah while non-peforming financing has a negative and insignificant effect on margin murabahah. However, simultaneously operating expense, third party fund and non peforming financing have a positive and significant impact on margin murabahah.
\end{abstract}

\begin{abstract}
Abstraks
Tujuan penelitian ini bertujuan untuk mengetahui pengaruh biaya operasional, dana pihak ketiga dan non peforming financing terhadap margin murabahah pada Bank Umum Syariah di Indonesia. Populasi penelitian adalah Bank Umum Syariah di Indonesia, adapun teknik pengambilan sampel yang digunakan adalah purposive sampling dengan sampel yang terpilih sebanyak 5 Bank Umum Syariah. Teknik pengumpulan data dalam penelitian ini menggunakan telaah dokumen, yaitu pengumpulan data dilakukan dengan menelaah laporan keuangan perusahaan. Teknik pengolahan dan analisis data yang digunakan adalah analisis akuntansi, analisis statistik deskriptif, analisis regresi linier berganda, uji asumsi klasik, analisis koefesien determinan $\mathrm{R}^{2}$ dan uji hipotesis dengan menggunakan SPSS versi 20. Berdasarkan uji hipotesis secara parsial biaya operasional dan dana pihak ketiga berpengaruh positif dan signifikan terhadap margin murabahah sedangkan non peforming financing berpengaruh negatif dan tidak signifikan terhadap margin murabahah. Namun, secara simultan biaya operasional, dana pihak ketiga dan non peforming financing berpengaruh positif dan signifikan terhadap margin murabahah.
\end{abstract}

\section{Pendahuluan}

Perkembangan perbankan syariah dewasa kini bisa bersaing dengan perbankan konvensional yang sudah terlebih dahulu berdiri. Banyak pihak meragukan keberhasilan ekonomi syariah termasuk perbankan syariah di Indonesia, namun terbukti pada masa krisis ekonomi di tahun 1998 di mana perbankan konvensional banyak yang mengalami kebangkrutan sedangkan di sisi lain bank syariah yang awalnya diragukan masih mampu bertahan dan berkembang. Hal ini disebabkan karena bank konvensional mengunakan bunga yang relatif tetap tanpa mempertimbangkan besarnya pendapatan bank, sedangkan untuk bank syariah mempertimbangkan pendapatan bank setiap bulannya.

Perbankan syariah merupakan lembaga keuangan yang memiliki fungsi untuk menghimpun dana masyarakat serta menyalurkannya dengan mekanisme syariah. Penghimpunan dana dilakukan melalui simpanan dan investasi seperti giro, wadiah, tabungan, dan deposito berjangka. Produk yang ditawarkan oleh perbankan syariah dapat dibagi menjadi 3 (tiga) bagian, yaitu produk penyaluran dana (financing), produk penghimpunan dana (funding), dan produk jasa (service). Produk penyaluran dana meliputi pembiayaan dengan prinsip jual beli (murabahah, salam, dan istishna), prinsip sewa (ijarah dan ijarah muntahiyat bittamlik), dan prinsip bagi hasil (mudharabah dan musyarakah). Dalam produk penyaluran dana di sini perbankan syariah pada umumnya menggunakan murabahah sebagai metode pembiayaan yang utama. (Sudarsono \& Miranti, 2018; Widyastuti \& Hendrieanto, 2010). 
Salah satu produk unggulan pembiayaan bank syariah adalah pembiayaan murabahah. Pembiayaan murabahah merupakan pembiayaan bank syariah dengan prinsip jual beli dengan kesepakatan keuntungan (margin) dan jangka waktu tertentu. Dari sisi penawaran bank syariah, pembiayaan murabahah dinilai lebih minim risiko dibandingkan pembiayaan bagi hasil. Dengan ditentukannya margin di awal akan memudahkan bank dalam memprediksi keuntungan yang akan diperoleh. Sementara dari sisi permintaan nasabah, tingginya pembiayaan murabahah disebabkan oleh pola perilaku konsumtif masyarakat yang cenderung meningkat. (Hamsyi, 2017; Hasanuddin, 2010).

Margin dipengaruhi oleh dua faktor, faktor eksternal dan internal. Faktor eksternal antara lain perubahan teknologi pengiriman jasa, kompetisi, hukum, dan peraturan lembaga keuangan serta kebijakan pemerintah. Faktor internal antara lain efisiensi penggunaan sumber daya, pengendalian biaya, kebijakan manajemen perpajakan, posisi likuiditas, dan posisi risiko. (Rose \& Kolari, 2009). Berbagai faktor ini mempengaruhi besarnya margin yang akan didapat oleh bank syariah. Margin yang menunjukkan kinerja bank dipengaruhi oleh faktor-faktor spesifik yang ada dalam bank itu sendiri, yaitu risiko, pengaruh pasar uang, dan biaya-biaya terkait pengurusan kegiatan bank. (Flamini, et al, 2009).

Dari hasil penelitian sebelumnya ada beberapa faktor yang mempengaruhi margin murabahah. Isa et al (2012) menunjukkan bahwa beberapa faktor penentu tingkat keuntungan pembiayaan murabahah di Malaysia melibatkan beberapa komponen seperti biaya dana, biaya overhead, biaya premi risiko, dan margin keuntungan. Akuisisi biaya dana dipahami sebagai keuntungan bagi deposan dan investor. Untuk biaya overhead, fukaha setuju dengan biaya yang berkontribusi untuk produk tetapi tidak dengan biaya periode.Demikian juga, biaya premi risiko juga diterima, di mana biaya ini bertujuan untuk mengkompensasi dari kerugian dan risiko yang terlibat dalam bisnis. Margin keuntungan dalam perbankan Islam di Malaysia sudah tercantum tepat dalam kontrak akadnya sehingga tidak lagi menimbulkan keraguan akan keuntungan yang tidak tercantum dan diketahui di dalam kontrak akadnya.

Rahma, Y (2016) menguji faktor-faktor yang mempengaruh margin murabahah yaitu target laba yang diproksi oleh return on asset (ROA), pembiayaan dan biaya overhead, bagi hasil dana pihak ketiga. Dengan menggunakan data keuangan dari 11 bank syariah di Indonesia. Penelitian ini menggunakan analisis regresi berganda untuk menguji faktor-faktor yang mempengaruh margin murabahah. Hasil penelitian ini menunjukkan bahwa return on asset, pembiayaan dan biaya overhead tidak berpengaruh terhadap margin murabahah secara parsial, namun besarnya tingkat pendanaan bank syariah mempengaruhi manajenen bank untuk menetapkan tingkat margin murabahah.

Yusuf dan Sari (2013) menganalisis faktor-faktor yang mempengaruhi tingkat perolehan margin pembiayaan dengan akad murabahah pada bank Syariah dan untuk mengetahui faktor yang paling berpengaruh terhadap tingkat perolehan margin murababah. Metode yang digunakan menngunakan pendekatan kuantitatif dengan mengunakan data sekunder dan penelitian lapangan. Hasil penelitian menunjukkan bahwa faktor yang memengaruhi tingkat margin pembiayaan murabahah adalah faktor biaya overhead memiliki pengaruh cukup besar dalam mnentukan besaran margin pembiayaan. Demikian juga dengan tingkat biaya administrasi turut mempengaruhi manajemen dalam menentukan besaran margin pembiayaan murabahah Sedangkan volume pembiayaan tidak berpengaruh terhadap tingkat perolehan margin Imurabahah.

Penelitian Wahyuni (2015) menguji faktor-faktor yang mempengaruhi marjin pembiayaan murabahah konsumtif pada bank Kaltim Syariah. Alat analisis yang digunakan adalah regresi linier berganda. Hasil olah data menunjukkan bahwa FDR, BOPO, Inflasi dan suku bunga berpengaruh secara simultan signifikan terhadap margin murabahah. Variabel yang paling berpengaruh adalah inflasi karena beta Inflasi lebih besar nilai beta dari FDR, BOPO, dan suku bunga. Keadaan ini disebabkan kenaikan inflasi akan meningkatkan biaya produksi sehingga mempengaruhi kenaikan harga barang dan jasa. Kondisi ini berdampak pada penurunan daya beli beli masyarakat berkurang sehingga mengakibatkan permintaan pembiayaan murabahah menurun. Penurunan permintaan pembiayaan murabahah diikuti oleh penurunan margin.

Arun (2010) meneliti pengaruh biaya overhead, bagi hasil dana pihak ketiga dan profit target terhadap margin pembiayaan murabahah pada Bank Muamalat Indonesia cabang Jambi. Penelitian ini dilakukan terhadap pembiayaan murabahah dengan menggunakan model regresi linier berganda untuk melihat pengaruh biaya overhead, bagi hasil dana pihak ketiga dan profit target terhadap margin pembiayaan murabahah. Hasil penelitian ini menunjukkan bahwa kenaikan biaya overhead berpengaruh terhadap kenaikan margin pembiayaan murabahah, sedangkan porsi bagi hasil dana pihak ketiga dan profit target tidak berpengaruh signifikan terhadap margin pembiayaan murabahah.

Susanto et al (2016) menggunakan kuadrat kecil atau ordinary least squares (OLS) untuk mengetahui faktor-faktor yang mempengaruhi terhadap pembiayaan murabahah di BTN Syariah. Tujuan dari penelitian ini adalah untuk menganalisis faktor-faktor NPF, Sertifikat Wadiah Simpanan Bank Indonesia dan deposito simpanan terhadap pembiayaan murabahah di BTN Syariah. Data yang digunakan dalam penelitian ini diperoleh dari beberapa sumber kegiatan untuk mendapatkan laporan keuangan di BTN Syariah. Hasil penelitian ini 
menunjukkan bahwa NPF tidak mempengaruhi pembiayaan murabahah di BTN Syariah, Sertifikat Wadiah Bank Indonesia berpengaruh signifikan terhadap pembiayaan murabahah BTN Syariah, Deposito simpanan tidak berpengaruh terhadap pembiayaan murabahah, berpengaruh signifikan terhadap profit margin murabahah pembiayaan pembiayaan terhadap rasio deposito berpengaruh signifikan terhadap pembiayaan murabahah di BTN Syariah.

Tingkat margin akad murabahah berpengaruh terhadap tingkat bagi hasil pemegang saham bagi hasil yang diberikan kepada anggota penyimpan dana. Hal ini dikarenakan murabahah merupakan produk pembiayaan terbesar dibanding dengan produk pembiayaan lain di lembaga keuangan syariah. Rahmawati \& Rokhman (2015) menganalisis variabel yang berpengaruh terhadap penetapan profit margin pada pembiayaan murabahah. Regresi linear berganda digunakan untuk menganalisi pengaruh variabel biaya operasional, profit target, cost of fund, risk cost dan tingkat rata-rata marjin pasar terhadap profit margin. Hasil oleh data menunjukkan bahwa faktor biaya operasional, risk of cost, dan rata-rata margin pasar berpengaruh signifikan terhadap penetapan profit margin. Sementar itu, cost of fund dan profit target tidak berpengaruh terhadap profit margin pada pembiayaan murabahah di BMT Se-Kabupaten Jepara. (Rahmawati \& Rokhman, 2015).

Lapoliwa \& Kuswandi (2009), menyebutkan bahwa biaya operasional adalah biaya yang diperlukan dalam operasi bank sehari-hari untuk mengolah transaksi. Terdiri dari biaya tenaga kerja, biaya administrasi dan umum, biaya penyusutan dan biaya lainnya yang terkait dengan operasional bank syariah. Kuncoro \& Suhardjono (2009), menyebutkan dana pihak ketiga adalah dana masyarakat merupakan dana terbesar yang dimiliki oleh bank dan ini sesuai dengan fungsi bank sebagai penghimpun dana dari yang kelebihan dalam masyarakat. Sementara itu, NPF menggambarkan antara pembiayaan yang bermasalah dengan total pembiayaan yang disalurkan oleh bank syariah (Siamat, 2009).

Berdasarkan latar belakang tersebut maka rumusan penelitian ini dapat dibuat dalam suatu pertanyaan bagaimana pengaruh biaya operasional, dana pihak ketiga (DPK), dan non performing Financing (NPF) terhadap margin murabahah. Dari rumusan tersebut diharapkan penelitian ini akan dapat mengetahui besarnya pengaruh tingkat biaya operasional, tingkat DPK, dan NPF terhadap tingkat margin murabahah.

\section{Metode Penelitian}

Penelitian ini menggunakan lima bank umum syariah. Metode pengumpulan data yang digunakan dalam penelitian ini adalah data sekunder. Menurut (Sugiyono, 2014) data sekunder (secondary data) adalah sumber data penelitian yang diperoleh peneliti secara tidak langsung melalui media perantara. Data sekunder pada umumnya didapat/dikumpulkan peneliti dari semua sumber yang sudah ada dalam artian peneliti sebagai tangan kedua. Data sekunder dapat berupa bukti, catatan atau laporan historis yang telah tersusun dalam arsip, baik yang dipublikasikan maupun yang tidak dipublikasikan.

Margin Murabahah dapat diukur dengan pendapatan margin murabahah per tahun. (Ghozali, 2009). Sedangkan, biaya operasional dapat diukur dengan besarnya biaya tenaga kerja, biaya administrasi dan umum, biaya penyusutan, dan biaya lainnya yang termasuk dalam biaya operasional. (Lapoliwa \& Kuswandi, 2009). Dana Pihak Ketiga (DPK) merupakan pertambahan giro, tabungan dan deposito. Dan, NPF diperoleh dari jumlah pembiayaan bermasalah dari pembiayaan murabahah dengan kolektibilitas kelompok yaitu kurang lancar, Diragukan, dan Macet dalam catatan atas laporan keuangan piutang murabahah.

\section{Pembahasan}

Pada Tabel 1 di bawah ini dapat dilihat bahwa variabel biaya operasional dengan nilai terendah adalah 54,48 diperoleh dari bank BCA Syariah pada tahun 2011 sedangkan nilai tertinggi sebesar 1.293,57 diperoleh dari bank BNI Syariah pada tahun 2017 dengan rata-rata nilai 625,72 dan standar deviasi 446,99. Sedangkan variabel DPK dengan nilai terendah 864,10 diperoleh dari bank BCA Syariah pada tahun 2011 sedangkan nilai tertinggi sebesar 2.9379,00 diperoleh dari bank BNI Syariah pada tahun 2017 dengan rata-rata nilai 9.300,95 dan standar deviasi 7.899,24.

Tabel 1. Descriptive Statistics

\begin{tabular}{lllllc}
\hline & $\mathrm{N}$ & Minimum & Maximum & Mean & Std. Deviation \\
\hline Biaya Operasional & 35 & 54,48 & 1293,57 & 625,7206 & 446,99185 \\
Dana Pihak Ketiga & 35 & 864,10 & 29379,00 & 9300,9534 & 7899,24234 \\
Non Peforming Financing & 35 &, 58 & 815,04 & 200,6731 & 195,82667 \\
Margin Murabahah & 35 & 29,64 & 2090,20 & 732,9023 & 604,01420 \\
Valid N (listwise) & 35 & & & \\
\hline
\end{tabular}

Sumber: Output SPSS Versi 20, 2018 
Variabel NPF dengan nilai terendah 0,58 diperoleh dari bank BCA Syariah pada tahun 2011 sedangkan nilai tertinggi sebesar 815,04 diperoleh dari Bank BRI Syariah pada tahun 2017 dengan rata-rata nilai 200,67 dan standar deviasi 195,82. Dan, variabel Margin Murabahah dengan nilai terendah 29,64 diperoleh dari Bank BCA Syariah pada tahun 2011 sedangkan nilai tertinggi sebesar 2.090,20 diperoleh dari bank BNI Syariah pada tahun 2017 dengan rata-rata nilai 732,90 dan standar deviasi 604,01.

Alat analisis yang digunakan untuk menghitung normalitas adalah dengan menggunakan teknik statistik non parametris sehingga diperoleh variabel margin murabahah berdistribusi normal. Berdasarkan hasil pengujian diperoleh bahwa nilai VIF pada Biaya Operasional sebesar 3,048, DPK sebesar 6,557, dan NPF sebesar 5,791 yang berarti tidak melebihi angka 10 (VIF < 10). Kemudian nilai tolerance biaya operasional sebesar 0,328, dana pihak ketiga 0,153 dan NPF sebesar 0.173 tidak kurang dari 0.10 (tolerance < 10). Maka dapat disimpulkan bahwa model regresi pada penelitian ini tidak terjadi multikolinearitas.

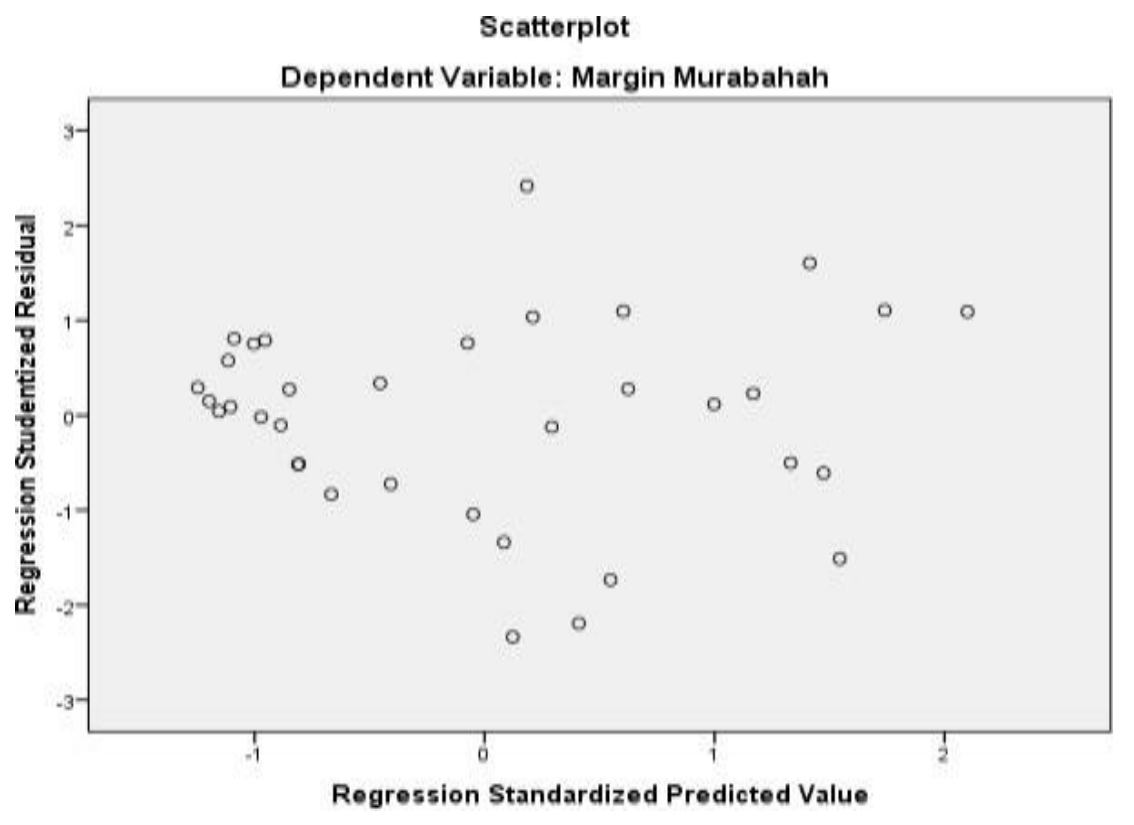

Pada grafik scatterplot tersebut menunjukkan titik-titik menyebar secara tidak teratur dan tidak membentuk pola tertentu, menyebar di atas dan di bawah angka 0 pada sumbu X, hal ini menunjukkan bahwa tidak ada heteroskedastisitas. Nilai Durbin-Watson (DW) sebesar 1,881. Jika dibandingkan dengan tabel pada nilai signifikansi $5 \%$, jumlah sampel $(\mathrm{n})=35$ dengan jumlah variabel independen $(\mathrm{k})=3$ maka dapat diperoleh nilai dL sebesar 1,2292 dan nilai dU 1,6500. Sehingga dapat dihitung $4-\mathrm{dU}=2,35$ dan $4-\mathrm{dL}=2,7708$ dan nilai $\mathrm{DW}=1,881$. Berdasarkan tabel pengambilan keputusan $\mathrm{dU}<\mathrm{dw}<4-\mathrm{dU}$ sehingga dapat disimpulkan tidak ada autokorelasi baik positif atau negatif.

Pengaruh biaya operasional terhadap margin murabahah menunjukkan nilai thitung > tabel $(9,878>$ 2,039) maka H1 diterima yang artinya biaya operasional secara parsial berpengaruh positif dan signifikan terhadap margin murabahah. Jika dilihat dari taraf signifikansinya sebesar $0,000<0,05$. Keadaan ini menunjukkan bahwa manajemen bank mempertimbangkan besaran biaya operasional dalam memperhitunkan tingkat margin murabahah bank syariah. Tingkat biaya operasional merupakan variabel pengurang penghasilan bank. Oleh karenanya bank perlu mempertimbangkan biaya operasional sebagai salah satu penentu tingkat prosentase margin guna menghindari kerugian yang hadapi bank

Tinkat DPK menentukan tingkat prosentase margin murabahah, nilai thitung > tabel $(5,885>2,039)$ maka $\mathrm{H}_{2}$ diterima yang artinya dana pihak ketiga secara parsial berpengaruh positif dan signifikan terhadap margin murabahah. Dengan ini hasil menunjukkan bahwa manajemen bank syariah berupaya mengurangi resiko pembiayaan dengan mempertimbangkan jumlah DPK yang disalurkan dalam bentuk pembiayaan. Apabila jumlah pembiayaan semakin tinggi maka prosentase muncul pembiayaan bermasalah akan semakin tinggi namun manajemen bank syariah melihat meningkatnya pembiayaan akan beresiko terhadap tingginya biaya bank oleh karena itu tingkat prosentase pembiayaan meningkat. Disamping itu, keadaan ekonomi makro yang cukup kondunsif bagi dunia usaha pada masa penelitian menjadikan manajemen bank berani menentuka margin murababah relatif lebih tinggi

Berdasarkan hasil uji regresi, pengaruh NPF terhadap margin murabahah menunjukkan nilai thitung < 
ttabel $(-1,428<2,039)$ maka H3 ditolak yang artinya non peforming financing secara parsial tidak signifikan terhadap margin murabahah. Dengan taraf signifikansi sebesar 0,149>0,05. Dengan ini hasil menunjukkan bahwa tingkat NPF tidak mempengaruhi manajemen bank dalam menentukan kebijakan margin murabahah. Manajemen bank kurang memperhitungkan resiko pembiayaan yang disalurkan ke sektor usaha untuk digunakan dalam menentukan margin murababah. Seharusnya semakin beresiko pembiayaan akan menurunkan besaran pembiayaan dengan cara meningkatkan margin murabahah namun manajemen tidak mempertimbankan NPF sebagai variabel yang cukup berpengaruh dalam menentukan margin murabahah. Hal ini disebabkan tingkat NPF bank syariah relatif stabil dan aman selama waktu penetitian

Berdasarkan uji $\mathrm{F}$ untuk pengujian hipotesis secara simultan bahwa nilai Fhitung 255,150> Ftabel $(3 ; 31)=2,91$ dan tingkat signifikansi sebesar $0,000<0,05$ dengan demikian dapat dikatakan bahwa biaya operasional, dana pihak ketiga, dan non performing financing secara bersama-sama berpengaruh positif dan signifikan terhadap margin murabahah. Sementar itu, berdasarkan hasil model summary ${ }^{b}$, bahwa diperoleh nilai sebesar 0.961, artinya 96,1\% variasi Margin Murabahah dapat dijelaskan oleh variabel Biaya Operasional, Dana Pihak Ketiga dan Non Peforming Financing, sedangkan sisanya $(100 \%-96,1 \%=3,9 \%)$ dijelaskan oleh variabel lain secara teoritis misalnya Financing to Deposit Ratio (FDR), Volume Pembiayaan dan Return on Asset (ROA).

\section{Kesimpulan}

Biaya operasional, DPK dan NPF secara bersama- sama memiliki pengaruh terhadap besaran margin murabahah. Manajemen bank syariah mempertimbangkan biaya operasional berpengaruh sebagai besaran yang digunakana sebagai pengurang pendapatan sehingga mempengaruhi margin murabahah. Tingkat besaran DPK menjadi indikator manajemen untuk menentukna margin murabahah. Sementara itu NPF tidak berpengaruh terhadap margin murabahah dikarenakan tingkat BPF relative stabil. Diharapkan pada penelitian selanjutnya untuk menambahkan beberapa variabel lainnya yang diduga mempengaruhi margin murabahah seperti net operating margin, return on asset dan capital adequacy ratio. Penelitian ini hanya dilakukan pada perbankan syariah yang masuk dalam golongan bank umum syariah, untuk penelitian selanjutnya diharapkan dapat menggunakan perbankan-perbankan selain perbankan syariah yang masuk dalam golongan bank umum syariah, karena memungkinkan adanya hasil lain dan kesimpulan yang berbeda pada saat melakukan penelitian selanjutnya.

\section{Daftar Pustaka}

Arum, E.D.P (2010), Pengaruh Biaya Overhead, Bagi Hasil, Dana Pihak Ketiga dan Profit Target terhadap Margin Pembiayaan Murabahah, 2(2), 409-419.

Bank Indonesia. (2016). Statistik Perbankan Indonesia. Diunduh 19 Maret, 2018 dari https://www.bi.go.id/statistik/perbanka n/indonesia/default.aspx.

Flamini, V, McDonald, C \& Liliana , (2009). The Determinants of Commercial Bank Profitability in SubSaharan Africa, IMF Working Paper, WP/09/15. 1-29.

Ghozali.A (2009). Serba-serbi Kredit Syariah: Jangan Ada Bunga di antara Kita. Jakarta: Elex Media Komputindo.

Hamsyi, N. F (2017). Analisis Penentuan Margin Pembiayaan Murabahah pada PT. Bank Syariah X Cabang Pontianank, Jurnal Ekonomi Bisnis dan Kewirausahaan, 6(3), 175-186.

Hasanuddin, M ( 2010). Analisis Pengaruh Dana Pihak Ketiga, Tingkat Suku Bunga Kredit, Non Performance Loan (NPL), dan Tingkat Inflasi terhadap Penyaluran Kredit Bank Perkreditan Rakyat (BPR) Di Jawa Tengah pada Tahun 2004-2012. Jurnal Akuntansi Politeknik Semarang. 5 (1), 25-31.

Isa, M. P, B, M, Rahman. A.B, Hasyim, H. B. M Hashim, \& Embong, A.M (2012) Shariah Views on the Components of Profit Rate in Al Murabahah Asset Financing in Malaysian Islamic Bank. International Journal of Social, Behavioral, Educational, Economic, Business and Industrial Engineering, 6 (7).

Kuncoro, M \& Suhardjono. (2002). Manajemen Perbankan Teori dan Aplikasi. Edisi Pertama. Yogyakarta, BPFE.

Otoritas Jasa Keuangan. (2017). Statistik Perbankan Syariah. Diunduh 20 Maret, 2018 dari https://www.ojk.go.id/id/kanal/syariah /data-dan-statistik/statistik-perbankan syariah/default.aspx.

Rahma, Y. (2016). Faktor-faktor yang Mempengaruhi Marin Murabahah bank Syariah di Indonesia, Akuntabilitas Jurnal Ilmu Akuntansi, (9(1), 43-54. 
Rahmawati, F, A \& Rokhman,W (2015). Analisis Faktor yang Mempengaruhi Penetapan Margin pada Pembiayaan Murabahah di BMT se Kabupaten Jepara, Equilibrium, 3(2), 238-253.

Rose, Peter S. dan James W. Kolari. (2009). Financial Institution : Understanding and Managing Financial Services. Amerika Serikat : Richard D. Irwin, Inc.

Siamat, D. (2004). Manajemen Bank Umum. Yogyakarta:Inter Media.

Sudarsono, H \& Miranti, A. S (2018), The Effect of Financial Performance toward Profit-Sharing Rate on Mudharabah Deposit of Sharia Banking in Indonesia, Jurnal Muqtashid, 9(1), 82-92.

Sugiyono. (2014). Metode Penelitian Pendidikan Pendekatan Kuantitatif, Kualitatif, dan R\&D. Bandung: Alfabeta.

Susanto, H, Sumarmawati, E.D \& Nurkholis (2016), Karakteristik Penentu Pembiayaan Murabahah pada Bank Tabungan negara (BTN) Syariah, Jurnal Ekonomi dan Keuangan Islam, 2(2), 21-27.

Wahyuni, T (2015), Faktor-faktor yang Mempengaruhi Penetapan Margin Murabahah Pembiayaan Konsumtif di Bank Kaltim Syariah, Jurnal Eksekutif, 2(1), 154-165.

Widyastuti, S \& Hendrieanto MB (2010), Pengaruh Volume Pembiayaan, Dana Pihak Ketiga, dan Biaya Intermediasi Terhadap Marjin Laba pada Bank Umum Syariah di Indonesia, Sinergi, 12 (1), 115-124.

Wiroso. (2009). Jual Beli Murabahah, Yogyakarta: UII Press.

Yusuf, M \& Sari, R.K (2013), Analisis Faktor-faktor yang Mempengaruhi tingkat Perolehan Margin dengan Akad Murabahah pada Bank Syariah X, Binus Business Review, 4(2), 687-696. 